Abstracta Iranicacta Iranica

Revue bibliographique pour le domaine irano-aryen

Volume 32-33 | 2013

Comptes rendus des publications de 2009-2010

\title{
Aḥmad Jām. Serāj al-sā’erīn. [Édition et commentaire de H. Nașīì Jāmī]
}

Ève Feuillebois-Piérunek

\section{(2) OpenEdition \\ 12 Journals}

Édition électronique

URL : http://journals.openedition.org/abstractairanica/39932

DOI : 10.4000/abstractairanica.39932

ISSN : 1961-960X

\section{Éditeur :}

CNRS (UMR 7528 Mondes iraniens et indiens), Éditions de l'IFRI

\section{Édition imprimée}

Date de publication : 1 décembre 2013

ISSN : 0240-8910

\section{Référence électronique}

Ève Feuillebois-Piérunek, « Aḥmad Jām. Serāj al-sāerīn. [Édition et commentaire de H. Nașīī Jāmī] », Abstracta Iranica [En ligne], Volume 32-33 | 2013, document 369, mis en ligne le 01 juillet 2016,

consulté le 26 septembre 2020. URL : http://journals.openedition.org/abstractairanica/39932 ; DOI : https://doi.org/10.4000/abstractairanica.39932

Ce document a été généré automatiquement le 26 septembre 2020.

Tous droits réservés 


\title{
Aḥmad Jām. Serāj al-sā’erīn. [Édition et commentaire de H. Nașīrī Jāmī]
}

\author{
Ève Feuillebois-Piérunek
}

\section{RÉFÉRENCE}

Aḥmad Jām. Serāj al-sāereīn. (Édition et commentaire de H. Nașīī Jāmī), Tehrān,

Pažūhešgāh-e 'olūm-e ensānī va moțāle'āt-e farhangī, 1389 [2010], 480 p.

1 La présente édition ne contient qu'un tiers de l'ouvrage original : comme beaucoup des œuvres d'Aḥmad Jām, ce traité ne nous est parvenu qu'incomplet. Notre connaissance de l'auteur est défigurée par l'image peu flatteuse qu'en donnent les Maqāmāt-e Žende Pìl, écrites par un disciple peu inspiré du maître, Sadīd al-Dīn Ġaznavī. Or, les Maqāmāt ont longtemps constitué la source la plus importante pour la biographie et la pensée d'Ahmad Jām, contribuant à une mauvaise réception de celles-ci. Il faut cependant signaler l'excellent travail d'Alī Fāḍel.

2 Cet ouvrage est édité à partir du seul manuscrit disponible et comporte une introduction et vingt-quatre chapitres. L'introduction insiste sur le caractère révélé ou tiré de l'expérience personnelle des idées exprimées dans le texte : l'auteur fait allusion à son propre cheminement spirituel. Le chapitrage est basé sur des couples opposés de termes ou de notions qui sont d'abord définis avant d'être différenciés à travers des citations coraniques, des contes, des vers et des poèmes. La construction de l'ouvrage n'est pas d'Aḥmad Jām lui-même; le texte porte nettement l'empreinte de l'oralité, étant la retranscription de l'enseignement du maître au cours d'assemblées avec les disciples.

3 Son caractère est moral et social : c'est un homme conscient des vicissitudes de la vie et des travers de son époque qui s'exprime ici, fustigeant la corruption, l'injustice, la tyrannie, l'inconduite, l'avidité, l'indifférence religieuse, le conformisme social, la 
crainte des puissants, la fausseté, l'humiliation des gens de bien. Son discours s'apparente à la littérature de conseil et à la prédication : il exhorte ses auditeurs à la recherche de la justice et de la sincérité, encourage les comportements vertueux, insiste sur le repentir et la réparation des erreurs, la droiture de l'intention, le service du prochain. Il est conscient que la voie qu'il propose est ardue et s'oppose aux usages du monde, mais il faut s'y laisser guider par la sagesse et l'intellect.

4 Cette édition jette un jour nouveau sur la pensée encore largement méconnue d'Ahmad Jām.

\section{AUTEURS}

\section{ÈVE FEUILLEBOIS-PIÉRUNEK}

Université Sorbonne Nouvelle- Paris 3, Mondes iranien et indien, Paris 